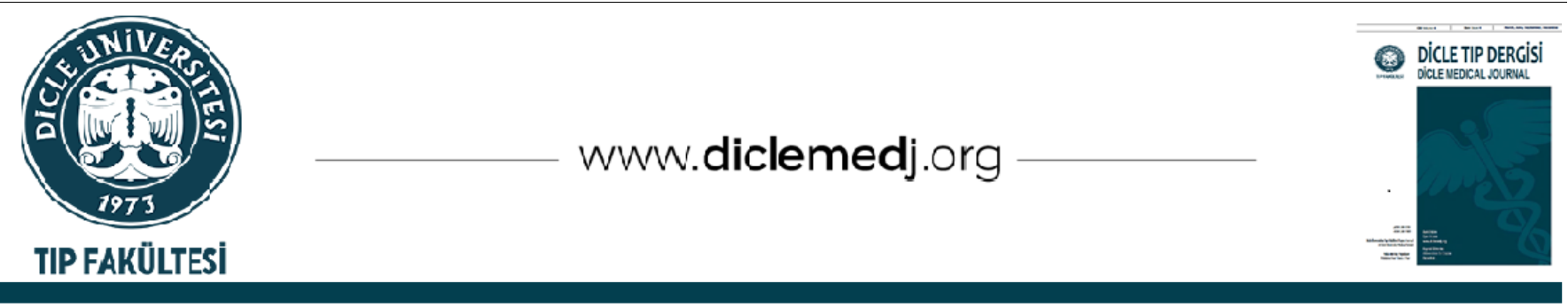

Derleme / Review

\title{
COVID-19 ve Aşı
}

\section{Saim Dayan iD 1}

1 Dicle Üniversitesi Tıp Fakültesi Enfeksiyon Hastalıkları ve Klinik Mikrobiyoloji ABD. Diyarbakır, Türkiye

Geliş: 19.08.2021; Kabul Tarihi: 29.09.2021

\section{Öz}

Günümüzdeki on büyük halk sağlığı başarısından en önemlisi aşılamadır. Aşılama, hastalığa karşı bireysel korumayı sağlamanın yanı sıra aynı zamanda bir toplumsal dayanıșma örneğidir. Bir toplumda așı ile bağıșıklama oranı \%85-95 gibi yüksek düzeyde ise aşılanmamıș kırılgan kesimler de korunmuş olur.

COVID-19 hastalı̆̆ına neden olan SARS-CoV-2 pandemisi, alınan tüm bireysel ve ulusal önlemlere rağmen yeni mutasyonlarla yayılmaya devam etmektedir. Henüz etkili bir antiviral ilaç mevcut olmadığından hastalıkla mücadelenin şimdilik en önemli yöntemi aşılamadır. Bir yıl gibi kısa sürede COVID-19 aşıları geliștirilmiș ve acil kullanım onayı ile küresel ölçekte kullanılmaya bașlanmıștır. Bir pandemi așısının bu kadar kısa sürede bulunmuș olması insanlık adına çok büyük bir başarıdır.

Halen 60 ülkede preklinik çalıșmalar da dahil olmak üzere toplam 408 aşı çalışması mevcuttur. Klinik faz çalışmaları aşamasında olan aşı sayısı 138'dir (Faz 1: 36, Faz 2: 65, Faz 3: 31). Klinik faz çalışmaları aşamasında olan 6 aşı çalışması sonlandırılmıştır. 21 aşıya acil kullanım onayı verilmiştir. Bu aşı adayları içerisinde geleneksel olarak başvurulan yöntemlere ek olarak daha önce hiç ruhsatlandırılmamış yeni teknolojiler de bulunmaktadır.

Anahtar kelimeler: SARS-CoV-2, COVID-19 aşıSı, SARS-CoV-2 varyantları

\section{COVID-19 and Vaccine}

\section{Abstract}

The most important of the ten great public health achievements today is vaccination. Vaccination is an example of social solidarity as well as providing individual protection against disease. If the rate of immunization with the vaccine is as high as $85-95 \%$ in a society, vulnerable populations who are not vaccinated are also protected.

The SARS-CoV-2 pandemic, which caused the COVID-19 disease, continues to spread with new mutations despite all individual and national measures taken. Since there is no effective antiviral drug yet, the most important method of fighting the disease is vaccination. In a short period of one year, COVID-19 vaccines were developed and started to be used on a global scale with emergency use approval. The discovery of a pandemic vaccine in such a short time is a great achievement for humanity.

A total of 408 vaccine studies are currently available, including preclinical studies in 60 countries. The number of vaccines currently in clinical phase studies is 138 (Phase 1: 36, Phase 2: 65, Phase 3: 31). 6 vaccine studies, which are in clinical phase studies, have been terminated. 21 vaccines have been approved for immediate use. Among these vaccine candidates, in addition to the traditional methods, there are also new technologies that have never been licensed before.

Keywords: SARS-CoV-2, COVID-19 vaccine, SARS-CoV-2 variants.

DOI: 10.5798/dicletip.1005040

Yazışma Adresi / Correspondence: Saim Dayan, Dicle Üniversitesi Tıp Fakültesi Enfeksiyon Hastalıkları ve Klinik Mikrobiyoloji ABD. Diyarbakır, Türkiye e-Mail: saimdayan@hotmail.com 


\section{GíRiş}

İnsan vücudu bir patojen ile karşılaştı̆̆ında doğal ve edinsel bağışıklık sistemleri devreye girer. Doğal bağışıklık sistemi, antijene özgü olmayan ve patojeni yok etmeye yönelik faaliyette bulunan nötrofil, makrofaj, doğal öldürücü (NK) hücreler, dentritik hücreler ve kompleman sisteminden oluşur. Vücuttaki antijen seviyesi belli bir eşiği geçtiğinde humoral ve hücresel bağışıklıktan oluşan çok daha kompleks ve antijene spesifik edinsel bağışıklık sistemi devreye girer. Aşılarla edinsel bağışıklık uyarılarak hastalıklar önlenmeye çalışılmaktadır ${ }^{1}$.

Küresel düzeyde Genişletilmiş Bağışılklama Programının uygulanması ile her yil 2.5 milyon 5 yaş altı çocuk ölümünün önlendiği bilinmektedir. Ülkemizde aşı sayesinde çocuk felci 1998, yeni doğan tetanozu 2009 yılından itibaren elimine edilmiş durumdadır. Çiçek hastalığı ise 1980 yılından itibaren dünyada eradike edilmiştir.

Son yıllarda sosyal medyanın da etkisi ile giderek artan aşı kararsızlığı ve karşıtlığı kızamık gibi birçok enfeksiyon hastalığının yeniden artmasına yol açmıştır. Dünya Sağlık Örgütüne (DSÖ) göre 2019 da dünyadaki en büyük 10 tehditten birisi aşı karşıtlığıdır. Maalesef COVID-19 aşılarına karşı da yaygın şekilde aşı karşıtı faaliyetler devam etmektedir.

Toplumda bir enfeksiyon hastalığına karşı bağışıklık kazanmış bireylerin sayısı belli bir oranın üzerinde olursa ancak o zaman hastalığın toplumda yayılması azalır. COVID-19 pandemisinin başından beri kullanılan "sürü bağışıklığı-herd immunity" ifadesi, toplum bağışıklığını ifade etmektedir. Her bulaşıcı hastalık için gereken toplum bağışıklık oranı hastalık etkeninin bulaşma hızına ve aşıların etkinlik oranlarına göre değişkenlik gösterir.
Küresel ölçekte alınan tüm önlemlere ve aşılama çalışmalarına rağmen SARS-CoV-2 pandemisi yeni mutasyonlar ve varyantlarla yayılmaya devam etmektedir. 14 Ağustos 2021 tarihi itibariyle dünya genelinde toplam COVID19 vaka sayısı: 207.268.728, Covid-19 nedeniyle ölüm sayısı ise: 4.363 .385 'tir. Aynı tarihte Türkiye'de toplam COVID-19 vaka sayısi: 6.039.857, COVID-19 nedeniyle ölüm sayısı ise : $52.860^{\prime}$ tır $^{2}$.

Bir bakıma COVID-19 pandemisi dünya için çok önemli bir tecrübe olmuştur. Örneğin Ebola gibi mortalite oranı yüksek ve SARS-CoV-2 gibi de yayılma hızı yüksek bir virüsle böyle bir pandemi yaşanmış olsaydı, tahmin edilemeyecek oranda büyük tahribata neden olabilirdi. Pandeminin ilk dönemlerinde insanlık çok hazırlıksız yakalanmış, gelişmiş ülkelerde bile maske, koruyucu ekipman ve dezenfektan malzeme temininde güçlükler çekilmiştir. Ancak yaşanan bu pandemi sayesinde ileride karşılaşılması muhtemel pandemilerde alınacak kişisel, ulusal ve uluslararası önlemler ile pandeminin yönetimi konusunda önemli bir tecrübe oluşmuştur.

Önümüzdeki yıllarda da koronavirüs ve benzeri virüslerle yeni pandemilerin ortaya çıkması kuvvetle muhtemeldir. $\mathrm{Bu}$ nedenle küresel ölçekte aşı teknolojilerinin geliştirilmesi, üretilmesi, depolanması ve adil dağıtımı için DSÖ önderliğinde hazırlıklar yapılmalıdır.

Acil kullanım onayı alan aşılar, 2020 yılının sonlarından itibaren bir çok ülkede uygulanmaya başlanmıștır. Bugüne kadar dünya nüfusunun \%31,2'sine en az bir doz COVID-19 aşısı uygulanmıştır. Dünya nüfusunun \%23,5'i tam aşılıdır. Dünya çapında toplam 4,7 milyar doz aşı uygulanmıștır. Halen günde 36,67 milyon doz aşı uygulanmaktadır. Düşük gelirli ülkelerdeki insanların sadece $\% 1,2$ 'sine en az bir doz aşı uygulanmıştır³. 


\section{COVID-19 için geliştirilen aşı tipleri}

COVID-19 aşıları birkaç farklı platform kullanılarak geliștirilmektedir. Bunlar sırasıyla komple viron aşıları (canlı attenüe, inaktif), nükleik asit bazlı DNA ve mRNA aşıları, viral vektör aşıları (replikatif ve nonreplikatif) ve rekombinant protein [protein subunit ve virus like particle (VLP) ] aşılarıdır. Bu aşıların çalışma prensipleri aşağıdadır:

İnaktif aşılar: İnaktif aşılar, hücre kültüründe SARS-CoV-2'nin üretilmesi ve ardından virüsün kimyasal olarak inaktive edilmesiyle üretilir ${ }^{4}$. İnaktive edilmiş virüs, genellikle bağışıklık tepkisini güçlendirmek için alüminyum gibi bir adjuvan ile birleştirilir. İnaktif aşlar intramüsküler uygulanır. Üretim için biyogüvenlik seviyesi 3 tesisi gerektirirler. SARS-CoV-2 inaktif aşısı ile oluşan bağışıklık cevabı, yalnızca spike proteinini değil, aynı zamanda virüsün diğer bileşenlerini de hedef alacaktır. Kullanımdaki inaktif COVID-19 aşılarının çoğu Çin ve Hindistan tarafından geliştirilmiştir. Sinovac'ın ürettiği Coronavac aşısı bu yöntemle hazırlanmıştır. İnaktif aşıların üretimi zordur ve vücutta replike olmadıklarından doz tekrarı gerekir.

Canlı zayıflatılmış (atenüe) aşılar: Vahşi tip virüs, genetik olarak modifiye edilerek veya olumsuz koşullarda pasajlanarak virülansı ortadan kaldırllır, ancak immünojenisitesi korunur. Zayıflatılmış bu virüs, bağışıklık tepkisi oluşturmak için alıcıda çoğalır, ancak hastalığa neden olmaz ${ }^{4}$ Canlı atenüe COVID-19 aşısının, zayıflatılmış virüsün birden fazla bileșenine karşı hem hümoral hem de hücresel bağışıklığı uyardığı bilinmektedir. Canlı atenüe aşıların bir diğer avantajı, intranazal olarak uygulanabilmeleridir. Bu sayede üst solunum yolu viral giriş bölgesinde mukozal bağışıklık sağlayarak virüsün girişini önleyebilir. Bununla birlikte, canlı atenüe aşılarla ilgili, vahşi tip virüse geri dönmesi veya onunla rekombinasyonu gibi güvenlik endişeleri de söz konusudur. Birkaç canlı atenüe COVID-19 aşısı klinik öncesi geliștirme așamasındadır. Henüz hiç biri insan denemelerine ulaşmamıştır5.

RNA aşılarl: RNA aşıları, SARS-CoV 2 için üretilen ve tamamen yeni bir aşı yaklaşımını temsil eden aşılardır. Pfizer/BioNTech aşısı insanlar üzerinde kullanılmak için onaylanmış ilk mRNA aşısı olmakla birlikte, 20 yıldan fazla süredir insanlarda kansere ve başka enfeksiyonlara karşı aşı geliştirilmesi için denenmekte olan bir teknolojidir. SARS-CoV 2 örneğinde aşı, spike proteinini kodlayan mRNA'dan oluşur. Hücreye verilen mRNA, burada okunur ve spike proteinleri sentezlenir. Vücuda aşı olarak viral protein vermek yerine söz konusu proteini sentezleyecek genetik materyal verilmektedir. Kolay yıkıma uğrayan RNA'yı korumak için mRNA molekülünü saran bir lipid nanopartikül (LNP) içinde verilir. Hücre içine girdikten sonra hücredeki lipazlar LNP yapısını parçalar ve mRNA sitoplazmada serbest hale gelir. mRNA daki kodlar okunarak hücre içinde sentezlenen spike proteini hücre dişına çlkarak hem humoral (antikor), hem de hücresel ( $\mathrm{T}$ hücre) immüniteyi uyararak istenen bağışıklığı oluşturur. mRNA hücre sitoplazmasında kalır ve kesinlikle çekirdeğe girmez. Dolayısıyla alıcının DNA'sı ile etkileşime girmez veya onunla bütünleşmez ve sitoplazmada 72 saat içinde yıkıma uğrar. mRNA çok kolay yıkıma uğradığından dolayı çok düşük sıcaklıklarda muhafaza edilmesi gerekmektedir6.

\section{Vektör aşıları}

Vektör aşılarında RNA, adenovirüs gibi canlı ya da cansız vektörler içine konarak vücuda verilir. Böylece söz konusu RNA'nın istenen proteinleri üretmesi ve o proteinlerin de immün sistemi uyarması hedeflenir.

Replikatif vektör aşıları; Replikatif özelliğe sahip vektörler, zayıflatılmış virüs suşlarından üretilir. Replikatif vektörler, aşılanmış bireylerde çoğalma özelliğine sahip olduklarından dolayı bağışıklık sistemini daha 
güçlü şekilde uyarırlar. $\mathrm{Bu}$ nedenle oluşturdukları bağışıklık nonreplikatif vektör aşılarına göre daha güçlüdür. Replikatif viral vektör aşlarına örnek yeni onaylanan Ebola aşısıdır. İnfluenza virüsü, kızamık aşısı suşu, veziküler stomatit virüsü ve Newcastle hastalığı virüsünü replikatif virüs olarak kullanıp spike proteinini eksprese edecek şekilde tasarlanmış COVID-19 aşı adayları mevcuttur 5,7,8. Bu tür aşılar viral giriş bölgesinde mukozal bağışıklığı uyarmak için intranazal olarak da verilebilirler. Birkaç replikatif vektör aşısı, erken faz klinik denemelerindedir.

Nonreplikatif vektör aşıları; Çoğalma yeteneği olmayan vektörler kullanılarak ve bağışıklık hedefi amaçlanan viral proteini eksprese edecek şekilde tasarlanmış aşılardır. Viral vektör aşlarda en çok adenovirüs kullanılmaktadır. Vektör aşılarının bir dezavantajı, vektöre karşı önceden var olan bağışıklığın aşının immünojenisitesini azaltabilmesidir9. İnsanlarda yaygın olmayan şempanze adenovirüsü gibi vektörler kullanılarak bu durum önlenebilir. Geliştirme aşamasındaki veya geliştirilmiş çoğu SARS-CoV2 replikatif vektör aşıları, spike proteinini eksprese edecek şekilde tasarlanmıştır.

Rekombinant protein aşları: Rekombinant protein așları, viral proteinlerden olușur. Protein subünit aşılarda genellikle virüsün spike proteinine veya reseptör bağlanma kısmına odaklanılmaktadır. $\mathrm{Bu}$ aşıların etkinliğini artırmak için bağışıklık uyarıcı adjuvanlar kullanmak gerekebilir. Virus like particle (VLP) kullanıldığı aşılarda boş virüs kabuk antijenleri kullanılır. Genetik materyalden yoksun oldukları için bulaşıcı değildirler. Güçlü bir bağıșıklık oluşturabilirler, ancak üretimleri zordur. Geliştirilmekte olan rekombinant COVID-19 aşıları arasında rekombinant spike protein aşıları, rekombinant reseptör bağlayıcı alan aşıları ve virüs benzeri partikül (VLP) aşıları yer almaktadır5.

\section{Acil Kullanım Onayı (EUA) alan bazı COVID- 19 aşılarının özellikleri}

Pfizer/BioNTech (BNT162b2): mRNA temelli bir aşıdır. Semptomatik covid-19'a etkinliği $\% 95$ 'tir. 3 hafta ara ile her biri 0,3 ml'lik iki intramüsküler doz şeklinde uygulanmaktadır. Normal saklama isısı -60 ila $-80 \stackrel{\circ}{ } \mathrm{C}$ arasıdır. Bu ortamdan çıkarıldıktan sonra -15 ila $-25{ }^{\circ} \mathrm{C}$ arasındaki ısıda 2 hafta süre ile saklanabilir. Normal aşıların saklama ısısı olan 2 ila $8 \stackrel{\circ}{ } \mathrm{C}$ arasındaki ısıda ise bir ay süre ile saklanabilir.

Nadir görülen yan etkiler arasında yaklaşık olarak 5 milyonda bir oranında görülen anafilaksi ve 16-39 yaşları arasındaki kişilerde milyonda 16 oranında görülen miyokardit/perikardit yer almaktadır ${ }^{10}$.

ABD'de Pfizer/BioNTech (BNT162b2) aşısına, 12 yaş ve üzeri bireylerde acil kullanım onayı (EUA) verilmiştir ${ }^{11}$.

Pfizer/BioNTech (BNT162b2) aşısının varyantlara etkinliği ile ilgili yapılan bir çalışmada BNT162b2 aşısı ile, iki dozun etkinliği alfa varyantı olan kişilerde \%93.7, delta varyantı olan kişilerde ise \%88,0 olarak bildirilmiştir ${ }^{12}$.

Nature'de yayınlanan bir çalışmanın sonuçlarına göre SARS-CoV-2 enfeksiyonu geçirildikten sonra gelişen humoral bağışık yanıtın en az bir yıl devam ettiği gösterilmiștir. Ayrıca hastalı̆̆ geçirdikten sonra mRNA aşılarını alan bireylerin, humoral bağışık yanitınin SARS-CoV-2 varyantlarını da kapsayacak şekilde ciddi anlamda güçlendiği tespit edilmiştir ${ }^{13}$.

Moderna (mRNA-1273): mRNA temelli bir aşıdır. Semptomatik COVID-19'a etkinliği \%94'tür. 4 hafta ara ile 0,5 ml'lik 2 intramüsküler doz şeklinde uygulanmaktadır. Normal saklama ısısı -15 ila $-25{ }^{\circ} \mathrm{C}$ arasıdır. Sonrasında 2 ila $8{ }^{\circ} \mathrm{C}$ arasındaki ısıda bir ay süre ile saklanabilir. 
Nadir görülen yan etkiler arasında ise yaklașık olarak 2.8 milyonda bir oranında görülen anafilaksi ve 16-39 yaşları arasındaki kişilerde milyonda 16 oranında görülen miyokardit/perikardit yer almaktadır ${ }^{10}$.

ABD'de Moderna (mRNA-1273) aşısına, 18 yaş ve üzeri bireylerde acil kullanım izni (EUA) verilmiștirir ${ }^{14}$

Yapılan bir çalışmada mRNA aşıları (mRNA1273, BNT162b2) ile iki doz aşılanmış olmasına rağmen SARS-CoV-2 ile enfekte olanlarda, aşı olmayanlara göre viral RNA yükü, ateşli semptom riski ve hastalık süresi daha düşük bulunmuştur ${ }^{15}$.

Janssen/Johnson \& Johnson (Ad26.COV2.S): Nonreplikatif adenovirüs 26 'nın kullanıldığı bir vektör aşısıdır. Orta ve şiddetli COVID-19'a karşı etkinliği \%66, şiddetli olgulara karşı etkinliği \%85'dir. 0,5 ml'lik tek bir intramüsküler doz şeklinde uygulanmaktadır.

Nadir yan etki olarak trombositopeni ile ilişkili trombotik komplikasyonlar görülebilmektedir:

- 30-39 yaş arası kadınlar için: 12.4 vaka/milyon

- 40-49 yaş arası kadınlar için: 9,4 vaka/milyon

- Diğer yaş aralıklarındaki kadınlar ve erkekler için: 1,3 ila 4,7 vaka/milyon

Nadir görülen bir diğer yan etki ise yaklaşık 8 vaka/milyon oranında görülen Guillain-Barre sendromudur ${ }^{10}$.

ABD'de Janssen/Johnson \& Johnson (Ad26.COV2.S) aşısına, 18 yaş ve üzeri bireylerde acil kullanım onayı verilmiştirit ${ }^{16}$.

AstraZeneca/University of Oxford/Serum Institute of India (ChAdOx1 nCoV19/AZD1222): Nonreplikatif şempanze adenovirüsünün kullanıldığı bir vektör aşısıdır. Semptomatik covid-19'a etkinliği \%70'tir'1. Üretici firma 4 ila 12 hafta ara ile iki doz şeklinde uygulanmasını önermektedir. DSÖ'nün önerisi ise 8 ila 12 hafta ara ile 2 doz şeklindedir.
ChAd0x1 nCoV-19/AZD1222 aşısının varyantlara etkinliği ile ilgili yapılan bir çalışmada bu aşının, iki dozunun etkinliği alfa varyantı olan kişilerde \%74.5, delta varyantı olan kişilerde ise $\% 67.0$ olarak saptanmıştır ${ }^{17}$.

Nadir yan etki olarak trombositopeni ile ilişkili trombotik komplikasyonlar görülebilmektedir:

- Serebral venöz sinüs trombozu: 169 vaka/34 milyon

- Splenik ven trombozu: 53 vaka/34 milyon

Nadir görülen bir diğer yan etki ise 227 vaka/51 milyon oranında görülen Guillain-Barre sendromudur ${ }^{10}$.

Novavax (NVX-CoV2373): Recombinant protein temelli bir aşıdır. 18-84 arası yetişkin katılımclarda semptomatik COVID-19'a etkinliği \%89.7 bulunmuştur. B.1.1.7 varyantına karşı da yüksek etkinlik göstermektedir. 3 hafta ara ile her biri 5- $\mu g^{\prime} l \mathrm{lk}$ iki intramüsküler doz şeklinde uygulanmaktadır ${ }^{18}$. Nadir görülen yan etkileri veri olmadığından bilinmiyor.

CanSino Biologics (Ad5-nCoV): Nonreplikatif adenovirüs 5'in kullanıldığı bir vektör aşısıdır. Etkinlik denemelerinden elde edilen veriler yayınlanmamıștır. Bir basın açıklamasında \%75'lik bir etkinlik oranı bildirilmiştir. Tek doz şeklinde uygulanmaktadır.

Bir dönem HIV aşı çalışmalarında kullanılan adenovirüs 5 vektörünün, sünnetsiz ve başlangıçta adenovirüs 5 için seropozitif olan erkek aşı alıcıları arasında HIV bulaşma riskini arttırdığı gözlemlenmiştir. $\mathrm{Bu}$ gözlemin adenovirüs 5 COVID-19 aşlarında da geçerli olup olmadığı belirsizdir. $\mathrm{Bu}$ nedenle araştırmacılar, bu yan etkiyle ilgili daha fazla araştırma yapılması gerektiğini ifade etmektedirler ${ }^{19}$. Nadir yan etkileri veri olmadığından bilinmiyor.

The Gamaleya National Center (Sputnik V): Spike glikoproteini içeren iki nonreplikatif adenovirüsün kullanıldığı bir vektör aşısıdır. Aşı iki doz şeklinde uygulanmaktadır. ilk önce 
adenovirüs 26 vektörü içeren aşı uygulanır, ardından 21 gün ila 3 ay sonra bir adenovirüs 5 vektör takviye dozu uygulanır.

20.000 'den fazla katılımcıyı içeren bir faz III çalışmasının ara analizine göre, bu aşının 21 . günden başlayarak semptomatik COVID-19'u önlemedeki etkinliği \%91,6'dır ${ }^{20}$. Herhangi bir ciddi yan etki görülmediği bildirilmiștir.

Sinopharm ( WIV04 ve HB02): İki farklı SARSCoV-2 izolatının kullanıldığı inaktive edilmiş tam virüs aşılarıdır. Her birinin bir alüminyum hidroksit adjuvanı vardır. Bu aşılar 28 gün arayla iki doz şeklinde uygulanır. Önceden SARS-CoV-2 enfeksiyonu geçirmemiş yaklaşık 40.000 katılımcıyı içeren bir faz III etkinlik çalışmasında, tam aşlamadan 14 gün sonra başlayan aşı etkinliği WIV04 için \%73, HB02 için ise \%78 olarak bildirilmiştir. Her hangi bir ciddi yan etki bildirilmemiştir ${ }^{21}$.

Sinovac (CoronaVac): İnaktive edilmiş tam virüs aşısıdır. Bir alüminyum hidroksit adjuvanına sahiptir. Așı, 28 gün arayla iki doz șeklinde uygulanmaktadır.

CoronaVac aşısının Türkiye'deki faz 3 klinik çalışma sonuçları, yayınlanan ilk faz 3 çalışmasıdır. Türkiye'de 18-59 yaşları arasında 10.000'den fazla katılımcının katıldığı faz 3 randomize kontrollü çalışmanın ara analizine göre, iki doz CoronaVac'ın, semptomatik covid19'a karşı etkinliğinin \%83.5 olduğu ve $\% 90$ oranında güçlü nötralizan antikor yanıtı Tablo I: Dünya Sağlık Örgütü EUL/PQ (Acil Kullanım Listesi/Önyeterlilik) değerlendirme sürecindeki COVID-19 aşılarının durumu (15 Temmuz 2021 verileri) ${ }^{26}$.

\begin{tabular}{|c|c|c|c|c|c|c|}
\hline & Üretici Firma & Aşı Adı & \begin{tabular}{|l|} 
Ulusal \\
Düzenleyici \\
Otorite kaydı
\end{tabular} & Aşı Tipi & $\begin{array}{l}\text { Onay } \\
\text { Durumu }\end{array}$ & Karar Tarihi \\
\hline 1 & Pfizer-Biontech & $\begin{array}{l}\text { BNT162b2/COMIRNATY } \\
\text { Tozinameran (INN) }\end{array}$ & EMA & Nucleoside modified mNRA & Onay & $31 / 12 / 2020$ \\
\hline 2 & $\begin{array}{l}\text { Oxford/ } \\
\text { AstraZeneca }\end{array}$ & AZD1222 & EMA & $\begin{array}{l}\text { Recombinant ChAdOx1 adenoviral } \\
\text { vector encoding the Spike protein } \\
\text { antigen of the SARS-CoV-2. }\end{array}$ & Onay & $16 / 04 / 2021$ \\
\hline 3 & $\begin{array}{l}\text { Oxford/ } \\
\text { AstraZeneca }\end{array}$ & AZD1222 & MFDS KOREA & $\begin{array}{l}\text { Recombinant ChAdOx1 adenoviral } \\
\text { vector encoding the Spike protein } \\
\text { antigen of the SARS-CoV-2. }\end{array}$ & Onay & $15 / 02 / 2021$ \\
\hline 4 & $\begin{array}{l}\text { Serum Institute of } \\
\text { India PVT.LTD }\end{array}$ & Covishield (ChAdOx1_nCoV19) & DCGI & $\begin{array}{l}\text { Recombinant ChAdOx1 adenoviral } \\
\text { vector encoding the Spike protein } \\
\text { antigen of the SARS-CoV-2. }\end{array}$ & Onay & $15 / 02 / 2021$ \\
\hline
\end{tabular}

oluşturduğu bildirilmiştir. Herhangi bir ciddi yan etki bildirilmemiştir.

Coronavac çalışmasının takip süresinin kısa olması, nispeten genç ve düşük risk grubundaki katılımcıların dahil edilmiş olması ve yeni varyantlar ortaya çıkmadan önce gerçekleşmiş olması nedeniyle daha fazla araștırmaya ihtiyaç $\operatorname{vardir}^{22}$.

Şili'de 2 Şubat - 1 Mayıs 2021 tarihleri arasında yürütülen ve yaklaşık 10,2 milyon kişiyi içeren çalışmada 2 doz CoronaVac aşısı uygulanmış bireylerde aşının genel etkinliği \%65,9 olarak saptanmıştır. Aynı çalışmada aşının COVID-19 hastalığı nedeniyle hastaneye yatışı önlemede \%87.5, yoğun bakım ünitesine yatışı önlemede $\% 90.3$ ve Covid-19 ile ilişkili ölümü önlemede $\% 86$ oranında etkili olduğu gösterilmiștir ${ }^{23}$.

Bharat Biotech, India (Covaxin): İnaktive edilmiş tam virüs aşısıdır. Bir alüminyum hidroksit ve bir reseptör agonisti adjuvanı içerir. 29 gün arayla iki doz şeklinde uygulanmaktadır. Herhangi bir ciddi yan etki bildirilmemiştir.

Hindistan'da geliştirilen ve kullanılan bir aşıdır. Hindistan'da yaygin olan B.1.617 (delta) varyantlarını da, vahşi tip virüste gözlemlenenden daha düşük titrelerde nötralize ettiği ve 25.800 katılımcı ile yapılan çalışmada, semptomatik COVID-19'a karşı \%81 oranında bir etkinliği olduğu bildirilmiştir24,25. 


\begin{tabular}{|c|c|c|c|c|c|c|}
\hline 5 & $\begin{array}{l}\text { Janssen/ } \\
\text { Johnson } \\
\text { Johnson }\end{array}$ & Ad26.COV2.S & EMA & $\begin{array}{l}\text { Recombinant, replication- } \\
\text { incompetent adenovirus type } \\
\text { 26 (Ad26) vectored vaccine } \\
\text { encoding the (SARS-CoV-2) Spike } \\
\text { (S) protein }\end{array}$ & Onay & $25 / 06 / 2021$ \\
\hline 6 & Moderna & mRNA-1273 & EMA & $\begin{array}{l}\text { mNRA-based vaccine } \\
\text { encapsulated in lipid } \\
\text { nanoparticle (LNP) }\end{array}$ & Onay & $30 / 04 / 2021$ \\
\hline 7 & Sinopharm / BIBP & $\begin{array}{l}\text { SARS-CoV-2 Vaccine (Vero Cell), } \\
\text { Inactivated (lnCoV) }\end{array}$ & NMPA & $\begin{array}{l}\text { Inactivated, produced in } \\
\text { Vero cells }\end{array}$ & Onay & $07 / 05 / 2021$ \\
\hline 8 & Sinovac & $\begin{array}{l}\text { COVID-19 Vaccine (Vero Cell), } \\
\text { Inactivated/ } \\
\text { CoronavacTM }\end{array}$ & NMPA & $\begin{array}{l}\text { Inactivated, produced in } \\
\text { Vero cells }\end{array}$ & Onay & $01 / 06 / 2021$ \\
\hline 9 & $\begin{array}{l}\text { TheGamaleya } \\
\text { National Center }\end{array}$ & Sputnik V & Russian NRA & $\begin{array}{l}\text { Human Adenovirus Vectorbased } \\
\text { Covid-19 vaccine }\end{array}$ & $\begin{array}{l}\text { Ek Veri } \\
\text { Gerekli }\end{array}$ & |-------- \\
\hline 10 & $\begin{array}{l}\text { Oxford/ } \\
\text { AstraZeneca }\end{array}$ & AZD1222 & \begin{tabular}{|l} 
Japan \\
MHLW/PMD \\
A
\end{tabular} & $\begin{array}{l}\text { Recombinant ChAdOx1 adenoviral } \\
\text { vector encoding the Spike protein } \\
\text { antigen of the SARS-CoV-2. }\end{array}$ & Onay & $09 / 07 / 2021$ \\
\hline 11 & $\begin{array}{l}\text { Oxford/ } \\
\text { AstraZeneca }\end{array}$ & AZD1222 & Australia TGA & $\begin{array}{l}\text { Recombinant ChAdOx1 adenoviral } \\
\text { vector encoding the Spike protein } \\
\text { antigen of the SARS-CoV-2. }\end{array}$ & Onay & $09 / 07 / 2021$ \\
\hline 12 & $\begin{array}{l}\text { Bharat Biotech, } \\
\text { India }\end{array}$ & $\begin{array}{l}\text { SARS-CoV-2 Vaccine, } \\
\text { Inactivated (Vero Cell)/ } \\
\text { COVAXIN }\end{array}$ & DCGI & $\begin{array}{l}\text { Whole-VirionInactivated } \\
\text { Vero Cell }\end{array}$ & $\begin{array}{l}\text { Onay } \\
\text { aşaması }\end{array}$ & ---- \\
\hline 13 & CanSinoBio & Ad5-nCoV & NMPA & $\begin{array}{l}\text { Recombinant Novel } \\
\text { Coronavirus Vaccine } \\
\text { (Adenovirus Type } 5 \text { Vector) }\end{array}$ & -------- & --------- \\
\hline 14 & Novavax & NVX-CoV2373/Covovax & EMA & $\begin{array}{l}\text { Recombinantnanoparticle } \\
\text { prefusion spike protein } \\
\text { formulated with Matrix- } \\
\mathrm{M}^{\mathrm{TM}} \text { adjuvant }\end{array}$ & & \\
\hline 15 & \begin{tabular}{|l|} 
Sinopharm / \\
WIBP2
\end{tabular} & \begin{tabular}{|l} 
Inactivated SARS-CoV-2 \\
Vaccine (Vero Cell)
\end{tabular} & NMPA & $\begin{array}{l}\text { Inactivated, produced in } \\
\text { Vero cells }\end{array}$ & -------- & |--------- \\
\hline 16 & CureVac & $\begin{array}{l}\text { Zorecimeran (INN) } \\
\text { concentrate and solvent for } \\
\text { dispersion for injection;Company } \\
\text { code: } \\
\text { CVnCoV/CV07050101 }\end{array}$ & EMA & $\begin{array}{l}\text { mNRA-based vaccine } \\
\text { encapsulated in lipid } \\
\text { nanoparticle (LNP) }\end{array}$ & -------- & ----------- \\
\hline 17 & Sanofi Pasteur & CoV2 preS dTM-AS03 vaccine & EMA & Recombinant, adjuvanted & |--------- & |--------- \\
\hline 18 & \begin{tabular}{|lr} 
Vector & State \\
Research & Centre \\
of Viralogy and \\
Biotechnology
\end{tabular} & EpiVacCorona & Russian NRA & Peptide antigen & -------- & ------ \\
\hline 19 & $\begin{array}{l}\text { Zhifei Longcom, } \\
\text { China }\end{array}$ & $\begin{array}{l}\text { Recombinant Novel } \\
\text { Coronavirus Vaccine (CHO Cell) }\end{array}$ & NMPA & Recombinant protein subunit & -------- & |--------- \\
\hline 20 & IMBCAMS, China & $\begin{array}{l}\text { SARS-CoV-2 Vaccine, } \\
\text { Inactivated (Vero Cell) }\end{array}$ & NMPA & Inactivated & --------- & |----------- \\
\hline 21 & $\begin{array}{l}\text { Clover Biopharma } \\
\text { ceuticals }\end{array}$ & SCB-2019 & EMA & $\begin{array}{l}\text { Novel recombinant SARSCoV-2 } \\
\text { Spike (S)-Trimer fusion protein }\end{array}$ & -------- & |----------- \\
\hline 22 & $\begin{array}{l}\text { BioCuba } \\
\text { Farma -Cuba }\end{array}$ & $\begin{array}{l}\text { Soberana 01, } \\
\text { Soberana 02 } \\
\text { Soberana Plus Abdala }\end{array}$ & CECMED & $\begin{array}{l}\text { SARS-CoV-2 spike protein } \\
\text { conjugated chemically to } \\
\text { meningococcal B or tetanus toxoid } \\
\text { or Aluminum }\end{array}$ & |-------- & ---- \\
\hline
\end{tabular}

\section{COVID-19 aşı yan etkileri}

Yaygin lokal ve sistemik reaksiyonlar: Enjeksiyon bölgesinde ağrı, kızarıklık, şişme, kaşıntı, aşının yapıldığı tarafta aksiller lenf nodu büyümesi, titreme, ateş, yorgunluk, eklem ağrısı ve baş ağrısı görülebilmektedir. Bunlar genellikle bütün COVID-19 aşılarından sonra değişik oranlarda karşılaştığımız yan etkilerdir. $\mathrm{Bu}$ reaksiyonlar geliştiğinde analjezikler veya antipiretikler kullanılabilirse de aşıya verilen konak immün yanıtı üzerindeki belirsiz etkileri nedeniyle profilaktik kullanımları önerilmemektedir. Bu tür yan etkiler genellikle 1-3 gün sürer ve çoğunlukla hafif seyreder. 
İkinci dozdan sonra görülen yan etkiler nispeten daha şiddetlidir.

Aşı yan etkisi olarak karşılaştığımız sorunlardan birisi de, özellikle adölesan ve genç erişkinlerde diğer aşıların uygulanması esnasında da gördüğümüz bayılmalardır. COVID-19 aşısının uygulanmasinı takiben 15 ila 30 dakika boyunca izleme, bayılma ile ilişkili yaralanma riskini azaltmaya yardımcı olabilir.

Bir diğer ciddi yan etki, mRNA aşıları (BNT162b2 ve mRNA-1273) sonrası çok nadir olarak gelişen anafilaksidir.

Ayrıca aşı olanlarda trombositopeni olmaksızın gelişen derin ven trombozu ve pulmoner emboli ile faysal paralizi ve kulak çınlaması rapor edilmiş, ancak bunlar aşıyla ilişkili yan etki olarak tanımlanmamıştır.

Aşı kontrendikasyonları: COVID-19 aşısının tek kontrendikasyonu, COVID-19 aşılarına veya bileşenlerine karşı gelişen alerjik reaksiyonlardır. mRNA așıları, Pfizer/BioNTech (BNT162b2) ve Moderna (mRNA-1273) aşılarından sonra anafilaktik reaksiyonlar bildirilmiştir. Anafilaksi vakalarının yüzde 80'i alerjik reaksiyon öyküsü olan kişilerde ve yüzde 90'ı 30 dakika içinde meydana gelmiştir. Bildirilen diğer alerjik reaksiyonlar arasında kaşıntı, döküntü, boğazda kaşınma hissi ve hafif solunum semptomları yer almaktadır. Pfizer/BioNTech (BNT162b2) aşılanmasını takiben bir milyon doz başına yaklaşık 5, Moderna (mRNA-1273) aşılarından sonra ise bir milyon doz başına 2.8 anafilaksi vakası rapor edilmiştir ${ }^{27}$.

mRNA aşllarl, Pfizer/BioNTech (BNT162b2) ve Moderna (mRNA-1273) her biri polietilen glikol ve vektör aşısı olan Janssen/Johnson \& Johnson (Ad26.COV2.S) ise polisorbat içerir. Bireylerde bu maddelere karşı alerji olması kontrendikasyon oluşturur.

Kişinin alerjik yapısına bağlı olarak mRNA aşısında görülen alerjik reaksiyonlar, potansiyel olarak vektör aşılarında da gelişebilir. Benzer şekilde vektör aşılarına karşı gelişen alerjik reaksiyonlar potansiyel olarak mRNA için de dikkatli olmayı gerektirir.

Herhangi bir aşı veya enjekte edilebilir tedavi sonrası anafilaksi veya herhangi bir nedenle anafilaksi öyküsü varsa aşı sonrası 30 dakika süre ile izlenmelidir. Așlar, ani alerjik reaksiyonların uygun şekilde yönetilebileceği ortamlarda uygulanmalıdır. Alerji öyküsü olmayan bireyler ise 15 dakika boyunca izlenmelidir.

\section{COVID-19 aşılarına bağlı özel güvenlik endișeleri:}

Covid-19 aşıları ile ilgili 3 önemli güvenlik endişesi mevcuttur: Trombositopeni ile ilişkili tromboz, myokardit/perikardit ve GuillainBarre sendromu

\section{Trombositopeni ile ilişkili tromboz:}

Hem Janssen/Johnson \& Johnson (Ad26.COV2.S) hem de AstraZeneca/University of Oxford/Serum Institute of India (ChAdOx1 nCoV-19/AZD1222) aşıları ile aşılananlarda trombositopeni ile ilişkili tromboz vakaları bildirilmiştir.

$\mathrm{Bu}$ vakaların çoğu, otoimmün heparin ilişsili trombositopeni (HIT) hastalarındakilere benzer şekilde, trombosit faktör 4 (PF4) antijenine karşı gelişen otoantikorlarla ilişkilendirilmiştir (28). Bu durum, aşıyla ilişkili immün trombotik trombositopeni (VITT) veya trombositopenik tromboz sendromu (TTS) olarak adlandırılmaktadır. VITT'de trombositopeni mevcuttur ve aşı olduktan yaklaşık 4-20 gün sonra ortaya çıkmaktadır. Tromboz; serebral venöz sinüste, splenik vende veya vücudun farklı yerlerinde ortaya çıkabilir.

AstraZeneca aşısından sonra gelişen trombositopeni ile ilişkili olağan dışı trombotik olayların çok nadir görülmesi ve COVID-19'un potansiyel yıkıcılı̆̆ Ajansı (EMA) ve DSÖ, aşının yararının 
risklerinden fazla olduğunu bildirerek aşının kullanılmaya devam edilmesini tavsiye etmiștir. Aşı olan kişilerde görülen trombozun özellikle 60 yaş altı kadınlarda tespit edildiğine dair veriler nedeniyle Almanya'nın da aralarında olduğu birçok Avrupa ülkesi, AstraZeneca aşısının 60 yaş altındakilere yapılmamasını önermiştir ${ }^{29}$. İngiltere ve Avrupa Birliği ülkelerinde AstraZeneca aşısı uygulanan yaklaşık 34 milyon kişiden 169'unda serebral venöz sinüs trombozu, 53'ünde ise splenik ven trombozu saptanmıştır ${ }^{30}$.

Janssen/Johnson \& Johnson (Ad26.COV2.S) aşısından sonra da çok nadir de olsa trombositopeni ile ilişkili trombotik olaylar görülmektedir.

Amerika Birleşik Devletleri'nde, Bağışıklama Uygulamaları Danışma Komitesi (ACIP), ölüm ve kritik hastalıkları önlemesi ve tek doz uygulama gibi yararları nedeniyle acil kullanım onayı (EUA) kapsamında kullanım tavsiyesini tekrarlamıştır ${ }^{31}$. Ancak ABD Gıda ve İlaç Dairesi (FDA) tromboz riski ortaya çıtıktan sonra Ad26.COV2.S kullanımına ara vermiștir ${ }^{32}$.

Ad26.COV2.S aşısı yapıldıktan sonra 30-39 yaş arası kadınlarda 12.4 vaka/milyon, 40-49 yaş arası kadınlarda 9,4 vaka/milyon, diğer yaș aralıklarındaki kadınlar ve erkeklerde ise 1,3 ila 4,7 vaka/milyon oranında trombositopeni ile ilişkili tromboz vakası görülmüştür ${ }^{33}$.

$\mathrm{Bu}$ aşıyı olanlar tromboz olasılı̆̆ı açısından bilgilendirilmelidirler. $\mathrm{Bu}$ kapsamda trombositopeniye bağlı olarak gelişen peteşi ve purpuralar ile trombotik komplikasyon olarak görülen nefes darlığı, alt ekstremitelerde ödem, göğüs ağrısı, karın ağrısı, baş ağrısı, sırt ağrısı ve fokal nörolojik semptomlar konusunda hasta uyarılmalıdır ${ }^{34}$.

\section{Myokardit:}

Pfizer/BioNTech (BNT162b2) ve Moderna (mRNA-1273) aşısı olan erkek adölesanlar ve genç erişkinlerde myokardit ve perikardit beklenenden daha slk bildirilmiştir. $\mathrm{Bu}$ aşılardan sonra 16-39 yaşları arasındaki kişilerde milyonda 16 oranında miyokardit/perikardit görülmektedir (33). Bulgular genellikle aşının uygulanmasından sonraki ilk hafta içinde ve daha yaygın olarak ikinci dozdan sonra ortaya çlkmaktadır.

mRNA aşılarından sonra gelişen miyokardit ve perikardit oranlarının çok düşük olması, hafif seyretmesi, tıbbi tedaviye iyi yanıt vermesi ve hızlı iyileşmesi göz önüne alındığında covid-19 hastalığının yıkıcı sonuçlarına tercih edilebileceği ortadadır. İlk dozda yan etki ortaya çıkmış ise ikinci doz ertelenebilir. COVID-19 riski yüksek ise myokardit epizodu düzeldikten sonra bu kişilere ikinci doz aşıları yapilabilir.

mRNA aşısı uygulandıktan sonra adölesanlarda ve genç erişkinlerde göğüs ağrısı, nefes darlığı veya çarpıntı geliştiğinde myokarditten şüphelenmek gerekir. $\mathrm{Bu}$ arada aşılyla eş zamanlı bulaşmış olan SARS-CoV-2 enfeksiyonunun da myokardit yapabileceği göz önünde bulundurulmalıdır 35 .

\section{Guillain-Barre sendromu (GBS):}

AstraZeneca ve Janssen/Johnson \& Johnson gibi adenovirüs vektör aşları ile Guillain-Barre sendromu arasında potansiyel bir ilişki araştırılıyor. Bu muhtemel yan etkiye rağmen, ABD Gıda ve İlaç Dairesi (FDA), ABD Hastalık Kontrol ve Önleme Merkezi (CDC) ve Avrupa İlaç Ajansı (EMA) bu aşıların faydalarının risklerinden daha ağır bastığını onaylamaktadır. SARS-CoV-2 enfeksiyonunun seyrinde de GBS vakaları bildirilmiștir. Geçirilmiş GBS öyküsü olan bireyler için adenovirüs vektör aşıları dışındaki COVID-19 aşılarının kullanılmasını önerilmektedir ${ }^{36}$.

AstraZeneca aşısı sonrası Guillain-Barre sendromu gelişme oranı yaklaşık 227 vaka/51 milyondur. Bu oran Janssen/Johnson \& Johnson aşısında 8 vaka/milyondur6. 


\section{Özel Gruplarda Covıd-19 Aşılaması}

SARS-CoV-2 enfeksiyonunu geçirmiş olanlar:

SARS-CoV-2 enfeksiyonu geçirmiş olanlardaki koruyuculuğun zamanla azalması nedeniyle hastalığı geçirenlerin de COVID-19 aşısı olması önerilmektedir. $\mathrm{Bu}$ bireylerde aşılama öncesi serolojik tarama önerilmemektedir. mRNA temelli COVID-19 aşılarında, ilk aşı dozundan sonra SARS-CoV-2 enfeksiyonu gelişmişse, ikinci doz yine de yapılmalıdır.

Hastalık geçirildikten ne kadar sonra aşı yapılması gerektiği ile ilgili olarak ülkeler ve otoriteler arasında görüş birliği olmamakla birlikte hastalık geçirildikten üç ay ve sonrasında aşı yaptırmanın uygun olacağı düşünülmektedir. Ayrıca CDC, COVID-19 için monoklonal antikor veya konvelesan plazma alan bireylerin tedavi tarihinden üç ay sonra aşılanabileceklerini önermektedir ${ }^{37}$.

Enfeksiyonu geçirmiş olanlarda aşılama, antikor düzeylerini ve koruma gücünü daha da artırmaktadır. Bazı çalışmalar, tek bir mRNA aşı dozundan sonra, SARS-CoV-2 enfeksiyonu geçirmiş olan bireylerin, SARS-CoV-2 naif bireylere klyasla önemli ölçüde daha yüksek nötralize edici antikor oluşturduklarını göstermiştir ${ }^{38}$.

Şu anda dünyada yaygın olarak görülen delta varyantının yayılmasının önlenmesi ve yeni varyantların ortaya çıkmasının engellenebilmesi için hastalığı geçirenlere delta varyantına daha etkili olan Pfizer/BioNTech (BNT162b2) aşısının uygulanması daha akılcı gözükmektedir.

SARS-CoV-2 enfeksiyonu esnasında multisistem inflamatuvar sendromu (MIS) gelişmiş olan hastalarda aşının da benzer tabloya neden olabileceği endișesi mevcuttur.

\section{İmmünsüpresif bireyler:}

Genel olarak hematolojik maligniteler, kök hücre veya solid organ nakli, HIV enfeksiyonu, CD4 hücre sayısının <200 olması, primer immün yetmezlikler, kemoterapötik ve immün süpresif ilaç kullanımı gibi durumlar immün süpresyon olarak kabul edilmektedir.

Mevcut araştırmalar, immünsüpresif hastalarda COVID-19 aşı etkinliğinin genel popülasyondakinden daha düşük olduğunu göstermektedir. Örneğin İsrail'de en az bir mRNA aşısı olan bir milyondan fazla kişinin katıldığı bir kohort çalışmasında, semptomatik COVID-19 için normalde \%94 olan aşı etkinliğinin, bağışıklığı baskılanmış hastalarda \%75'e düştüğü gösterilmiştir39. Aşıya rağmen COVID-19 nedeniyle hastaneye yatırılan hastaların yaklaşı \%40'ı immünsüpresif hastalardır ${ }^{40}$.

Bağışıklığı baskılanmış hastalarda 2 doz aşı uygulandıktan sonra 3. doz yapılması gündeme gelmiş ise de iki doz sonrasında bağışık yanıt oluşmayanlarda 3. dozdan sonra da oluşmadığı görülmüştür. $\mathrm{Bu}$ tür hastalarda koruyucu önlemlere devam edilmesi ve ev halkı ile diğer yakın temaslılarının aşılanmaları önerilmektedir.

\section{Gebeler:}

Gebelerde COVID-19 aşılarının güvenliğine ilişkin veriler sınırlı olmakla birlikte bu alanda yeni yapılan bir takım çalışmalar mevcuttur. Örneğin16 ila 54 yaşları arasındaki toplam 35.691 gebe katılımcı ile yapılan bir çalışmadaki ön bulgular, mRNA COVID-19 aşısı uygulanan gebeler arasında güvenlik açısından bariz yan etkinin görülmediği saptanmıştır. Bununla birlikte, özellikle hamileliğin ilk üç ayı olmak üzere gebelik ve bebek sonuçları üzerinde daha kapsamlı çalışmalar yapılması gerekmektedir ${ }^{41}$.

\section{Çocuklar:}

COVID-19 genellikle çocuklarda yetişkinlere göre daha hafif seyretmektedir. Buna rağmen toplumsal bağışılklığı oluşturmak ve çocukların hastalığı bulaştırabileceği kırılgan kesimleri korumak amacıyla çocukların da aşılanması önerilmektedir. 
Mevcut COVID-19 aşılarının bir kısmı, 16 yaş üzeri genç erişkinlere ait verilere sahiptir ve kullanılmaktadır. 16 yaş altı adölesanlarda covid19 aşı uygulaması ile ilgili yakın zamanda bir çalışma yayınlandı. 12 ila 15 yaş arasındaki 2260 adölesanın katıldığı 1131'inin BNT162b2 aşı ve 1129'nun plasebo kolunda olduğu bu çalışmada enjeksiyon yerinde ağrı, yorgunluk, baş ağrısı dışında ciddi yan etki görülmedi. $\mathrm{Bu}$ yaş grubunda, 16-25 yaş arası genç yetişkinlere göre daha fazla bağışıklık cevabı elde edildi. Aşılananlar arasında hiç COVID-19 vakası görülmezken plasebo grubunda 16 vaka saptandı. Gözlenen aşı etkinliği \%100 olarak saptandi ${ }^{42}$. Bu ve benzeri çalışmalara dayanarak ABD, 12-15 yaş arası adölesanlara BNT162b2 aşı iznini onaylamıştır. BNT162b2 dişındaki diğer aşılarla ve daha küçük çocuklarda yapılan çalışmalar devam etmektedir.

COVID-19 enfeksiyonunu takiben çocuklarda multisistem inflamatuvar sendrom (MIS-C) gelişme riski mevcuttur. MIS-C açısından altta yatan tıbbi durumları olan çocukların özellikle aşılanmaları istenmekle birlikte aşının bizatihi kendisinin de bu tabloya neden olabileceği endişesi vardır.

Türkiye'de 15 yaş üstü gençlere ve 12-15 arası kronik hastalığı olan adölesanlara aşılama tanımlanmış durumdadır.

\section{Aşılamada 3. doz yaklaşımı}

8 Temmuz 2021'de Pfizer ve BioNTech, COVID-19 aşılarının üçüncü ( booster) dozunun uygulanması için ABD ve Avrupa yetkili kurullarına müracaat edeceklerini açıkladılar ${ }^{43}$.

Aynı gün, ABD'nin yetkili kurulları olan FDA ve CDC, mevcut kanıtların bu takviye dozuna ihtiyaç olduğunu göstermediğini vurguladı. Buna rağmen İsrail, İngiltere, Fransa, Almanya, İsveç ve BAE gibi bazı ülkeler, booster dozun gerekliliğine dair daha fazla kanıt beklemeden yakında booster dozu uygulamaya başlayacaklarını belirtmiş durumdalar.

Așllar ülkeler arasında adil paylaşılmadığı takdirde aşıya ulaşamamış veya yeterince aşılanmamış ülkelerde gelişebilecek varyantlar nedeniyle aşılanmış ülke vatandaşları yine risk altına girecektir. $\mathrm{Bu}$ nedenle küresel çapta aşlamaya öncelik verilmesi, booster doz uygulamasından daha fazla yarar sağlayacaktır.

Küresel ölçekte tüm ülkeler yeterli düzeyde COVID-19 aşısına ulaşabilmiş veya mevcut aşılar artık yeni viral varyantlara karşı koruma sağlayamıyorsa booster doz düşünülebilir. İngiltere, Kanada ve Katar'dan gelen veriler, Pfizer-BioNTech aşılarının Delta varyantına karşı ciddi enfeksiyonu önlemede \%90'ın üzerinde etkili olduğunu göstermektedir ${ }^{44-46}$. Bu etkinlik zamanla azalsa bile, 3. dozların, aşılanmamış kişilere yönlendirilmesi, booster doz olarak kullanılmasından çok daha fazla hastaneye yatış ve ölüme karşı koruma sağlayacaktır.

Ocak 2021'den Haziran 2021'e kadar, ABD'de COVID-19'dan ölümlerin \%99'undan fazlası aşılanmamış kişilerden oluşmaktadır ${ }^{47}$. Demek ki mevcut aşılar, ölümden yeterince korumaktadır. Aşılama, COVID-19 nedeniyle hastaneye ve yoğun bakıma yatışı önlediği ve ölüme karşı koruma sağlamaya devam ettiği sürece, booster doz yerine bu aşıyı yeterince aşı temin edememiş ülkelerdeki bireylere yönlendirmek, pandeminin kontrol altına alınması ve aşılanmış kişilerin dirençli varyantlara maruz kalmasını önlemek adına daha doğru bir karardır.

10 Ağustos 2021 itibariyle son bir hafta içinde Covid-19'dan kişi başına en fazla ölümün yaşandığı ülkelerden Tunus, Gürcistan, Botsvana, Eswatini, Namibya ve Güney Afrika gibi ülkeler, aşıların adaletsiz dağılımı nedeniyle nüfuslarının ancak \%10'unu aşılamış durumdadırlar ${ }^{48}$. Kısacası, aşı eşitsizliği COVID-19'dan ölüm oranlarında eşitsizliklere dönüşmektedir.

\section{COVID-19 aşı pratiği}

Her aşı serisi, başlangıçta kullanılan aynı aşı ile tamamlanmalıdır. Örneğin ilk doz için kullanılan mRNA aşısı, ikinci dozun zamanı geldiğinde geçici olarak mevcut değilse, farklı bir mRNA aşısı ile seri tamamlanabilir. Aşılardan birinin birinci, diğerinin ise ikinci doz olarak kullanılmasının etkinliği ve güvenliği hakkında yeterli veri yoktur. 
İlk doz mRNA aşısı almış ancak kontrendikasyon nedeniyle ikinci doz için mRNA aşılarından herhangi birini alamayan kişilere Janssen/Johnson \& Johnson (Ad26.COV2.S) verilebilir. Bir seriyi tamamlamak için iki farklı aşının kullanımına ilişsin bazı kanıtlar, her iki doz için aynı aşının kullanılmasına kıyasla daha güçlü antijenik uyarıyla birlikte daha yüksek bir sistemik reaksiyon olușturmaktadır ${ }^{49}$.

İki dozluk seriler halinde verilen mRNA aşıları için ikinci doz, önerilenden daha erken olmamalıdır. Ancak gerektiğinde ikinci doz, ilk dozun 6 hafta sonrasına kadar geciktirilebilir. İkinci dozun, birinci dozdan altı haftadan fazla bir süre sonra verilmesi durumunda serinin tekrarlanması gerekmediği belirtilmiştir.

Bağışıklama Uygulamaları Danışma Komitesi (ACIP) daha önce COVID-19 dışı aşıların COVID19 aşılamasından sonraki 14 gün içinde uygulanmamasını önermişti. Ancak aşılamada gecikmelere ilişkin endişeler nedeniyle bu tavsiye revize edildi. Buna göre COVID-19 aşılarının diğer aşlarla ilgili olarak herhangi bir zamanda uygulanabileceği belirtilmiştir.

Aşıların bazı yan etkileri COVID-19 semptomları ile örtüşmektedir. Aşıdan hemen sonra ortaya çıkan ve bir veya iki gün içinde düzelen ateş, titreme, yorgunluk ve baş ağrısı aşıya verilen sistemik reaksiyona bağlıdır. Bununla birlikte, aşılamayı takiben veya birkaç gün sonra ortaya çıkan ve birkaç günden uzun süren semptomlar, eş zamanlı COVID-19'un göstergesi olabildiğinden test yapılmasını gerektirebilir.

Ateşle seyreden bir enfeksiyon hastalığ varlığında aşıya karşı yanıt azalabilir. Bu nedenle ateşli hastalık geçirmekte olan kişilerin 48 saatlik ateşsiz dönemden sonra aşllanmaları önerilmektedir.

Aşıların sağladığı bağışıklık sadece antikorlara bağlı değildir. Rutin testlerle hücresel ve sekretuvar bağışıklık düzeyleri ölçülemediği ve test standardizasyonu da henüz sağlanamadığı için aşı sonrası antikorların serolojik taraması önerilmemektedir.

\section{SARS-Cov 2 varyantları ve aşı etkinliği}

Salgın dönemlerinde bulaşma hızının artması sonucu mutasyon görülme sıklığının artmasına bağlı olarak yeni varyantlar ortaya çıkabilmektedir. Yeni varyantların bulaşma hızları dolaşımdaki diğer varyantlardan yüksek ise kısa zamanda baskın hale gelebilirler. Bu da hastalığın şiddetini, bireyin immün cevabını ve aşı etkinliğini değiştirerek salgının seyrini etkileyebilir.

SARS-CoV-2 varyantlarının adlandırılması ve izlenmesinde Pango, GISAID ve Nextstrain gibi kurumlar tarafından tanımlanan adlandırma sistemleri kullanılmaktadır. Sistemler arası karışıklığı gidermek üzere DSÖ Yunan alfabesinin kullanıldığı bir sınıflamayı kabul etmiştir. DSÖ sinıflamasında, SARS-CoV-2 varyantları iki grupta toplanmıştır ${ }^{50}$.

1- Endișe verici varyantlar (Variant of Concern: VOC). Tablo-2

2- Dikkate alınması gereken varyantlar (Variant of Interest : VOI).

Tablo II: Endişe verici varyantlar:

\begin{tabular}{|l|l|l|l|l|l|}
\hline DSÖ & Pango & GISAID & Nextstrain & $\begin{array}{l}\text { illk } \\
\text { saptama }\end{array}$ & $\begin{array}{l}\text { ilk } \\
\text { adlandırma }\end{array}$ \\
\hline Alpha & B.1.1.7 & $\begin{array}{l}\text { GRY } \\
\text { (formerly } \\
\text { GR/501Y.V) }\end{array}$ & 20I (V1) & $\begin{array}{l}\text { Ingiltere, } \\
\text { Eylül } \\
2020\end{array}$ & $\begin{array}{l}18 \quad \text { Aralık } \\
2020\end{array}$ \\
\hline Beta & B.1.351 & GH/501Y.V2 & 20H(V2) & $\begin{array}{l}\text { Güney } \\
\text { Afrika, } \\
\text { Mayıs } \\
2020\end{array}$ & $\begin{array}{l}18 \quad \text { Aralık } \\
2020\end{array}$ \\
\hline Gamma & P.1 & GR/501Y.V3 & 20J(V3) & $\begin{array}{l}\text { Brezilya, } \\
\text { Kasım } \\
2020\end{array}$ & $\begin{array}{l}11 \quad \text { Ocak } \\
2021\end{array}$ \\
\hline Delta & B.1.617.2 & G/478K.V1 & $21 \mathrm{~A}$ & $\begin{array}{l}\text { Hindistan, } \\
\text { Ekim } \\
2020\end{array}$ & $\begin{array}{l}11 \quad \text { Mayıs } \\
2021\end{array}$ \\
\hline
\end{tabular}

Dikkate alınması gereken varyantlar:

Epsilon (ABD, Mart 2020), Zeta (Brezilya, Nisan 2020), Eta (Çeşitli ülkeler, Aralık 2020), Theta 
(Filipinler, Ocak 2021), Iota (ABD, Kasım 2020), Kappa (Hindistan, Ekim 2020), Lambda (Peru, Aralık 2020).

Aşıların endișe verici varyantlara karşı koruma sağlayıp sağlayamadığına ilişkin veriler sınırlıdır. Bazıları yayınlanmış olan etkinlik çalışmalarından elde edilen verilere göre, COVID-19 aşıları varyantlara karşı etkili olmaya devam etmektedir. Ancak bu etkinlik özellikle Delta (B.1.617.2) ve Beta'ya (B.1.351) karşı zayıflamış durumdadır.

Geçirmekte olduğumuz pandemi süreci, varyantların seyahatler nedeniyle ülkeler arasında kolaylıkla yayılabileceğini ve bunlar arasında hibrit mutasyonların da gelişebileceğini göstermektedir. Așlamada hedeflenen sürü bağışıklığı kısa sürede ve tüm dünyada eşit düzeyde sağlanmadıkça yeni mutasyonlar ve yeni varyantlar ortaya çıkmaya devam edecektir. Așllar, kişileri korumak ve pandemiyi durdurmanın yanı sıra varyant gelişmesini engellemek için de en etkili yöntemdir.

En son 9 Ağustos 2021'de güncellenen aşların varyantlara etkinliği ile ilgili veriler, Tablo-3'de gösterilmiştir.

Tablo III: Aşıların SARS-CoV-2 varyantlarına etkinliği: Mevcut veriler ve tahmini modelleme ${ }^{51}$.

\begin{tabular}{|l|l|l|l|l|}
\hline Aşı Adı & $\begin{array}{l}\text { Hastalığı } \\
\text { önlemedeki } \\
\text { etkinliği } \\
\text { Orijinalvirüs } \\
\text { Alpha }\end{array}$ & $\begin{array}{l}\text { Enfeksiyon } \\
\text { ünlemedeki } \\
\text { etkinliği } \\
\text { Orijinalvirüs } \\
\text { Alpha }\end{array}$ & $\begin{array}{l}\text { Hastalı̆̆ı } \\
\text { otlemedeki } \\
\text { etkinliği } \\
\text { Beta,Gamm } \\
\text { a, Delta }\end{array}$ & $\begin{array}{l}\text { Enfeksiyonu } \\
\text { onlemedeki } \\
\text { etkinliği } \\
\text { Beta,Gamm } \\
\text { a, Delta }\end{array}$ \\
\hline Pfizer/BioNTech & $\% 92$ & $\% 86$ & $\% 90$ & $\% 78$ \\
\hline Moderna & $\% 94$ & $\% 89$ & $\% 93$ & $\% 80$ \\
\hline AstraZeneca & $\% 85$ & $\% 52$ & $\% 83$ & $\% 51$ \\
\hline $\begin{array}{l}\text { Johnson\&Johnso } \\
\text { n (Janssen) }\end{array}$ & $\% 86$ & $\% 72$ & $\% 85$ & $\% 56$ \\
\hline Sputnik-V & $\% 92$ & $\% 81$ & $\% 80$ & $\% 70$ \\
\hline Novavax & $\% 89$ & $\% 79$ & $\% 79$ & $\% 69$ \\
\hline CoronaVac & $\% 50$ & $\% 44$ & $\% 43$ & $\% 38$ \\
\hline Sinopharm & $\% 73$ & $\% 65$ & $\% 63$ & $\% 56$ \\
\hline Tianjin CanSino & $\% 66$ & $\% 58$ & $\% 57$ & $\% 50$ \\
\hline Covaxin & $\% 78$ & $\% 69$ & $\% 68$ & $\% 60$ \\
\hline
\end{tabular}

\section{Türkiye'de COVID-19 aşı çalışmaları}

Türkiye'de üç aşı acil kullanım onayı almış durumdadır. $\mathrm{Bu}$ aşılar: Pfizer/BioNTech (BNT162b2) mRNA aşısı , Sinovac (CoronaVac) inaktif aşı ve Gamaleya (Sputnik V) nonreplikatif viral vektör aşılarıdır. Türkiye'de COVID-19'a yönelik 11 adet preklinik ve klinik aşamada aşı çalışması mevcuttur. Türkiye'de klinik faz çalışmaları devam eden yerli aşılar52:

1. Türkiye Sağlık Enstitülerinin yürüttüğü ERUCOV-VAC. Aşı tipi: İnaktif, Faz 3 aşamasında 2. Türkiye Bilimsel ve Teknolojik Araştırma Kurumu (TÜBİTAK)'ın yürüttüğü SARS-CoV-2 VLP Vaccine Alpha Variant. Așı tipi: VLP, Faz 2 aşamasında

3. Türkiye Bilimsel ve Teknolojik Araştırma Kurumu (TÜBİTAK)'ın yürüttüğü SARS-CoV-2 VLP Vaccine. Aşı tipi: VLP, Faz 2 aşamasında

4. Kocak Farma'nın yürüttüğ̈: Koçak-19 İnaktif Adjuvanlı COVID-19 Vaccine, Aşı tipi: İnaktif, Faz 1 aşamasında

5. Türkiye Bilimsel ve Teknolojik Araştırma Kurumu (TÜBITTAK)'ın yürüttüğü Adjuvanted Inactivated Vaccine, Aşı tipi: İnaktif, Faz 1 aşamasında.

Türkiye'de Pfizer/BioNTech (BNT162b2) mRNA aşısı ve Sinovac (CoronaVac) aşılarının uygulaması devam etmektedir. Bu aşıların 3. doz uygulaması da başlatılmıştır. 14 Ağustos 2021 tarihi itibariyle Türkiye'de 18 yaş üstü nüfusta birinci doz aşı uygulananların oranı $\% 70,69$, ikinci doz aşı uygulananların oranı ise $\% 52,67$ 'dir. Türkiye'de bugüne kadar yapılan aşı sayısı 43 milyon 877 bin 460 'ı birinci doz, 32 milyon 691 bin 994'ü ikinci doz, 6 milyon 556 bin 728 'i üçüncü doz olmak üzere toplam 83 milyon 126 bin 182 'dir 53 .

Çıkar Çatışması Beyanı: Yazarlar çıkar çatışması olmadığını bildirmişlerdir.

Finansal Destek: Bu çalışma her hangi bir fon tarafından desteklenmemiștir. 
Declaration of ConflictingInterests: The authors declare that they have no conflict of interest.

Financial Disclosure: No financial support was received.

\section{KAYNAKLAR}

1. Zinkernagel RM. On natural and artificial vaccinations. Annu Rev Immunol. 2003;21:515-46. https://doi.org/10.1146/annurev.immunol. 21.120601.141045.

2. Worldometer. Reported Cases and Deaths by Country or Territory https://www.worldometers.info/coronavirus/ (Accessed on August 14, 2021).

3. Our World in Data. Coronavirus (COVID-19) Vaccinations https://ourworldindata.org/covidvaccinations (Accessed on August 14, 2021).

4. Gomez PL, Robinson JM. Vaccine Manufacturing. In: Plotkin's Vaccines, 7th, Plotkin S, Orenstein W, Offit P, Edwards K (Eds), Elsevier, 2018. p.51.

5. World Health Organization. Draft landscape of COVID-19 candidate vaccines. https://www.who.int/publications/m/item/draftlandscape-of-covid-19-candidate-vaccines (Accessed on October 20, 2020).

6. Yu J, Tostanoski LH, Peter $\mathrm{L}$, et al. DNA vaccine protection against SARS-CoV-2 in rhesus macaques. Science 2020; 369:806.

7. Case JB, Rothlauf PW, Chen RE, et al. ReplicationCompetent Vesicular Stomatitis Virus Vaccine Vector Protects against SARS-CoV-2-Mediated Pathogenesis in Mice. Cell Host Microbe 2020; 28:465.

8. Sun W, Leist SR, McCroskery S, et al.. Newcastle disease virus (NDV) expressing the spike protein of SARS-CoV-2 as vaccine candidate. bioRxiv. https://www.biorxiv.org/content/10.1101/2020.07. 26.221861v2 (Accessed on November 05, 2020).

9. Zhu FC, Li YH, Guan XH, et al. Safety, tolerability, and immunogenicity of a recombinant adenovirus type- 5 vectored COVID-19 vaccine: a dose-escalation, openlabel, non-randomised, first-in-human trial. Lancet 2020; 395:1845.

10. Connors M, Graham BS, Lane HC, Fauci AS. SARSCoV-2 Vaccines: Much Accomplished, Much to Learn. Ann Intern Med 2021; M21.
11. Emergency Use Authorization (EUA) of the PfizerBioNTech COVID-19 Vaccine to Prevent Coronavirus. Fact sheet for healthcare providers administering vaccine.

https://www.fda.gov/media/144413/download

(Accessed on February 25, 2021).

12. Lopez Bernal J, Andrews N, Gower C, Gallagher E, et al. Effectiveness of Covid-19 Vaccines against the B.1.617.2 (Delta) Variant. N Engl J Med. July 2021, N Engl J Med. 385:585-594 DOI: 10.1056/NEJMoa2108891.

13. Wang, Z., Muecksch, F., Schaefer-Babajew, D. et al. Naturally enhanced neutralizing breadth against SARS-CoV-2 one year after infection. Nature 595, 426431 (2021). https://doi.org/10.1038/s41586-02103696-9

14. Emergency Use Authorization (EUA) of the Moderna COVID-19 Vaccine to prevent Coronavirus Disease 2019 (COVID-19). Factsheet for healthcare providers administering vaccine.https://www.fda.gov/media/144637/downlo ad?utm_medium=email\&utm_source=govdelivery (Accessed on December 18, 2020).

15. M.G. Thompson, J.L. Burgess, A.L. Naleway, et al. Prevention and Attenuation of Covid-19 with the BNT162b2 and mRNA-1273 Vaccines. June 2021, N Engl J Med. DOI: 10.1056/NEJMoa2107058

16. US FDA. Emergency use authorization (EUA) of the Janssen COVID-19 vaccine to prevent coronavirus disease $2019 \quad$ (COVID-19). https://www.fda.gov/media/146304/download

(Accessed on March 01, 2021).

17. Lopez Bernal J, Andrews N, Gower C, Gallagher E, et al. Effectiveness of Covid-19 Vaccines against the B.1.617.2 (Delta) Variant. N Engl J Med. July 2021, N Engl J Med. 385:585-594 DOI: 10.1056/NEJMoa2108891.

18. P.T. Heath, E.P. Galiza, D.N. Baxter. Safety and Efficacy of NVX-CoV2373 Covid-19 Vaccine. N Engl J Med. June 2021. DOI: 10.1056/NEJMoa2107659.

19. Buchbinder SP, McElrath MJ, Dieffenbach C, Corey L. Use of adenovirus type-5 vectored vaccines: a cautionary tale. Lancet 2020; 396:e68.

20. Logunov DY, Dolzhikova IV, Zubkova OV, et al. Safety and immunogenicity of an rAd26 and rAd5 vector-based heterologous prime-boost COVID-19 vaccine in two formulations: two open, non- 
randomised phase $1 / 2$ studies from Russia. Lancet 2020; 396:887.

21. Kaabi NA, Zhang Y, Xia S, et al. Effect of 2 Inactivated SARS-CoV-2 Vaccines on Symptomatic COVID-19 Infection in Adults. JAMA 2021.

22. Tanriover, M. D., Doğanay, H. L., Akova M. at al. (2021). Efficacy and safety of an inactivated wholevirion SARS-CoV-2 vaccine (CoronaVac): interim results of a double-blind, randomised, placebocontrolled, phase 3 trial in Turkey. The Lancet. https://doi.org/10.1016/s0140-6736(21)01429-x

23. Alejandro Jara, Eduardo A. Undurraga, Cecilia González, et al. Effectiveness of an Inactivated SARSCoV-2 Vaccine in Chile. $\mathrm{N}$ Engl J Med. DOI: 10.1056/NEJMoa2107715

24. Bharat Biotech. Bharat Biotech Announces Phase 3 Results of COVAXIN: India's First COVID-19 Vaccine Demonstrates Interim Clinical Efficacy of $81 \%$. https://www.bharatbiotech.com/images/press/cova xin-phase3-efficacy-results.pdf (Accessed on May 06, 2021).

25. Kathryn M Edwards, MDWalter A Orenstein, MD. COVID-19: Vaccines to prevent SARS-CoV-2 infection. https://www.uptodate.com/contents/covid-19-

vaccines-to-prevent-sars-cov-2-infection (Accessed on Aug 16, 2021).

26. World Health Organization. https://extranet.who.int/pqweb/sites/default/files/d ocuments/Status_COVID_VAX_15July2021.pdf

(Accessed on July15, 2021).

27. Shimabukuro T. COVID-19 vaccine safety update, Advisory Committee on Immunization Practices (ACIP) meeting, January 27, 2021. https://www.cdc.gov/vaccines/acip/meetings/downl oads/slides-2021-01/06-COVID-Shimabukuro.pdf

(Accessed on January 28, 2021).

28. Pai M, Grill A, Ivers A, et al. Vaccine-Induced Prothrombotic Immune Thrombocytopenia (VIPIT) Following AstraZeneca COVID-19 Vaccination. https://covid19-

sciencetable.ca/sciencebrief/vaccine-inducedprothrombotic-immune-thrombocytopenia-vipitfollowing-astrazeneca-covid-19-vaccination/

(Accessed on March 31, 2021).

29. Dyer 0. Covid-19: EMA defends AstraZeneca vaccine as Germany and Canada halt rollouts. BMJ 2021; 373:n883.
30. European Medicines Agency. AstraZeneca's COVID19 vaccine: EMA finds possible link to very rare cases of unusual blood clots with low blood platelets. https://www.ema.europa.eu/en/news/astrazenecascovid-19-vaccine-ema-finds-possible-link-very-rarecases-unusual-blood-clots-low-blood (Accessed on April 07, 2021).

31. MacNeil JR, Su JR, Broder KR, et al.. Updated Recommendations from the Advisory Committee on Immunization Practices for Use of the Janssen (Johnson \& Johnson) COVID-19 Vaccine After Reports of Thrombosis with Thrombocytopenia Syndrome Among Vaccine Recipients - United States, April 2021. MMWR Morb Mortal Wkly Rep 2021.

32. US Food and Drug Administration. FDA and CDC Lift Recommended Pause on Johnson \& Johnson (Janssen) COVID-19 Vaccine Use Following Thorough Safety Review. https://www.fda.gov/news-events/pressannouncements/fda-and-cdc-lift-recommendedpause-johnson-johnson-janssen-covid-19-vaccineuse-following-thorough (Accessed on April 24, 2021).

33. Connors M, Graham BS, Lane HC, Fauci AS. SARSCoV-2 Vaccines: Much Accomplished, Much to Learn. Ann Intern Med 2021; M21. (önceden de atıf yapılmıştı)

34. European Medicines Agency. AstraZeneca's COVID19 vaccine: EMA finds possible link to very rare cases of unusual blood clots with low blood platelets. https://www.ema.europa.eu/en/news/astrazenecascovid-19-vaccine-ema-finds-possible-link-very-rarecases-unusual-blood-clots-low-blood (Accessed on April 07, 2021).

35. Gargano JW, Wallace M, Hadler SC, et al. Use of mRNA COVID-19 Vaccine After Reports of Myocarditis Among Vaccine Recipients: Update from the Advisory Committee on Immunization Practices - United States, June 2021. MMWR Morb Mortal Wkly Rep 2021; 70:977.

36. Abu-Rumeileh S, Abdelhak A, Foschi $M$, et al. Guillain-Barré syndrome spectrum associated with COVID-19: an up-to-date systematic review of 73 cases. J Neurol 2021; 268:1133.

37. Interim Clinical Considerations for Use of COVID-19 Vaccines Currently Authorized in the United States. https://www.cdc.gov/vaccines/covid-19/clinicalconsiderations/covid-19-vaccines-us.html (Accessed on July 23, 2021). 
38. Krammer F, Srivastava K, Alshammary H, et al. Antibody Responses in Seropositive Persons after a Single Dose of SARS-CoV-2 mRNA Vaccine. N Engl J Med 2021; 384:1372.

39. Chodick G, Tene L, Rotem RS, et al. The effectiveness of the TWO-DOSE BNT162b2 vaccine: analysis of realworld data. Clin Infect Dis 2021.

40. Brosh-Nissimov T, Orenbuch-Harroch E, Chowers $\mathrm{M}$, et al. BNT162b2 vaccine breakthrough: clinical characteristics of 152 fully-vaccinated hospitalized COVID-19 patients in Israel. Clin Microbiol Infect 2021.

41. Tom T. Shimabukuro, M.D., Shin Y. Kim, M.P.H., Tanya R. Myers, Ph.D., et al. Preliminary Findings of mRNA Covid-19 Vaccine Safety in Pregnant Persons N Engl J Med 384;24, June 17, 2021. https://www.nejm.org/doi/full/10.1056/nejmoa210 4983

42. Robert W. Frenck, Jr., M.D., Nicola P. Klein, M.D., Ph.D., Nicholas Kitchin, M.D., et al. Safety, Immunogenicity, and Efficacy of the BNT162b2 Covid19 Vaccine in Adolescents. N Engl J Med 385; 239-250. July 2021. DOI: $10.1056 /$ NEJMoa2107456

https://www.nejm.org/doi/full/10.1056/NEJMoa210 7456

43. Erman M, Steenhuysen J. Reuters website. Pfizer, BioNTech to seek authorization for COVID booster shot as Delta variant spreads. Published July 9, 2021. Accessed July 12, 2021. https://www.reuters.com/business/healthcarepharmaceuticals/pfizer-ask-fda-authorize-boosterdose-covidvaccine-delta-variant-spreads-2021-07$08 /$

44. Nasreen S, Chung $\mathrm{H}$, He S, et al. Effectiveness of COVID-19 vaccines against variants of concern in Ontario, Canada. bioRxiv. Preprint posted online July 16, 2021. doi:10.1101/2021.06.28.21259420

45. Abu-Raddad LJ, Chemaitelly $\mathrm{H}$, Butt AA, et al. Effectiveness of the BNT162b2 COVID-19 vaccine against the B.1.1.7 and B.1.351 variants. N Engl J Med. 2021;385(2):187-189. doi:10.1056/NEJMc2104974

46. Bernal JL, Andrews N, Gower C, et al. Effectiveness of COVID-19 vaccines against the

B.1.617.2 variant. bioRxiv. Preprint posted online May 24, 2021. doi:10.1101/2021.05.22.21257658

47. McEvoy J. 99.5\% Of people killed by COVID in last 6 months were unvaccinated, data suggests. Forbes. Published July 1, 2021. Accessed July 14, 2021. https://www.forbes.com/sites/jemimamcevoy/2021 /07/01/995-of-people-killedby-covid-in-last-6months-were-unvaccinateddata-

suggests/?sh=ac216ce493da

48. Holder J. The New York Times. Tracking coronavirus vaccinations around the world. Accessed August 10, 2021. https://www.nytimes.com/interactive/2021/world/ covid-vaccinationstracker.html

49. Interim Clinical Considerations for Use of COVID-19 Vaccines Currently Authorized in the United States. https://www.cdc.gov/vaccines/covid-19/clinicalconsiderations/covid-19-vaccines-us.html (Accessed on July 23, 2021).

50. World Health Organization. Tracking SARS-CoV-2 variants. https://www.who.int/activities/trackingSARS-CoV-2-variants/tracking-SARS-CoV-2-variants (Accessed on August 13, 2021).

51. Institute for Health Metrics and Evaluation. COVID19 vaccine efficacy summary http://www.healthdata.org/covid/covid-19-vaccineefficacy-summary (Accessed on August 9, 2021).

52. Covid19 Vaccine Tracker. Vaccines Candidates by Trial https://covid19.trackvaccines.org/vaccines/

(Accessed on August 15, 2021).

53. T.C. Sağlık Bakanlığı. COVID-19 Bilgilendirme Platformu https://covid19.saglik.gov.tr/ (Erişim tarihi 14 Ağustos 2021). 